\title{
Analisis Debit Limpasan dan Indeks Erosivitas Hujan pada Metode USLE Akibat Variasi Intensitas Hujan dengan Alat Rainfall Simulator
}

\section{Amalia Wara Respatiningrum ${ }^{1 *}$, Lily Montarcih Limantara ${ }^{1}$, Ussy Andawayanti $^{1}$}

${ }^{1}$ Jurusan Teknik Pengairan, Fakultas Teknik, Universitas Brawijaya, Jl. MT. Haryono No. 167, Malang, 65145, Indonesia

*Korespondensi Email: amaliawr@gmail.com

\begin{abstract}
The occurrence of rain causes many things, such as surface runoff and rainfall erosivity. The energy of rainfall can make soil eroded. This study aims to determine the effect of rainfall intensity variations on the resulting runoff discharge, rain erosivity index, and erosion rate using the USLE method on a rainfall simulator. A sampling of soil in Pandesari, Pujon, Malang. This study was conducted with rainfall variations, namely $0.5 \mathrm{liter} /$ minute, $1.0 \mathrm{liter} /$ minute, $1.5 \mathrm{liter} / \mathrm{minute}$, and 2.0 liter/minute with a rainfall simulator slope of $5 \%$. As a result, the rainfall intensity significantly affects the runoff discharge in the rainfall simulator, with a coefficient of determination $\mathrm{R}^{2}=0.981$. Rainfall intensity also affects the rainfall erosivity in the rainfall simulator with a coefficient of determination $\mathrm{R}^{2}=0.999$. And in the USLE method, the rate of erosion is generated by the rainfall intensity with a coefficient of determination $\mathrm{R}^{2}=0.999$.
\end{abstract}

Keywords: Erosion, Rainfall Erosivity, Rainfall Simulator, Runoff, USLE Method

Abstrak: Terjadinya hujan mengakibatkan banyak sekali hal, misalnya aliran permukaan dan juga erosivitas hujan. Energi hujan tersebut bisa membuat suatu lahan tererosi. Dalam penelitian ini bertujuan untuk mengetahui pengaruh variasi intensitas hujan terhadap debit limpasan yang dihasilkan, indeks erosivitas hujan, dan besar laju erosi dengan metode USLE pada alat rainfall simulator. Pengambilan sampel tanah di Desa Pandesari, Kecamatan Pujon, Kabupaten Malang. Studi ini dilakukan dengan variasi hujan yaitu $0,5 \mathrm{liter} / \mathrm{menit}, 1,0 \mathrm{liter} / \mathrm{menit}, 1,5 \mathrm{liter} / \mathrm{menit}$, dan 2,0 liter/menit dengan kemiringan alat rainfall simulator sebesar 5\%. Hasilnya, intensitas hujan sangat memengaruhi debit limpasan pada alat rainfall simulator, dengan koefisien determinasi $\mathrm{R}^{2}=0,981$. Intensitas hujan juga memengaruhi erosivitas hujan pada rainfall simulator dengan koefisien determinasi $\mathrm{R}^{2}=0,999$. Dan pada metode USLE, laju erosi yang dihasilkan dipengaruhi juga oleh intensitas hujan dengan koefisien determinasi $\mathrm{R}^{2}=0,999$.

Kata kunci: Erosi, Erosivitas Hujan, Limpasan, Metode USLE, Rainfall Simulator 


\section{Pendahuluan}

Setelah hujan turun, pertama-tama akan terserap masuk ke dalam tanah menjadi infiltrasi dan sisanya akan menjadi aliran permukaan (runoff). Namun di satu daerah di Indoensia dengan daerah yang lain, hujan tidak akan memiliki intensitas yang sama. Hal ini akan mengakibatkan pengaruh yang berbeda pula terhadap limpasan permukaan. Tidak semata-mata air akan turun begitu saja, melainkan energi dari hujan yang turun tersebut akan memiliki kemampuan untuk mengikis tanah dan menimbulkan erosi, hal ini disebut erosivitas hujan [1]. Beberapa faktor umum yang mengakibatkan terjadinya erosi yaitu faktor iklim teritama intensitas hujan, faktor topografi, faktor karakteristik tanah pada lahan, vegetasi penutup tanah, dan tataguna lahan tersebut [2]. Erosi ini menjadi penyebab utama berkurangnya produktivitas lahan pertanian, dan berkurangnya kapasitas saluran atau sungai akibat pengendapan material hasil erosi [3].

Dalam penelitian yang lain, curah hujan tahunan tertinggi dan terendah akan menghasilkan indeks erosivitas hujan tertinggi dan terendah juga [4]. Dengan besar intensitas hujan dan kemiringan lereng yang semakin tinggi, akan juga mengakibatkan tingginya limpasan [5]. Selain itu juga, peningkatan jumlah erosi yang terjadi, akan bertambah sesuai pertambahan pada intensitas hujan [6].

Dikarenakan hujan di suatu daerah tidak pasti dengan durasi yang tidak menentu, penelitian ini menggunakan alat rainfall simulator. Alat ini memiliki kemampuan untuk mensimulasikan hujan pada suatu lahan dengan kemiringan tertentu dan dengan mudah mengatur besarnya intensitas hujan tersebut. Hujan yang turun pada alat rainfall simulator ini akan turun dengan konstan dan durasi yang bisa diatur. Sehingga tujuan penelitian ini adalah untuk mengetahui pengaruh dari intensitas hujan terhadap debit limpasan permukaan pada alat rainfall simulator, indeks erosivitas hujan pada alat rainfall simulator dan pengaruhnya terhadap laju erosi pada alat rainfall simulator.

\section{Bahan dan Metode}

\subsection{Bahan}

Pada penelitian ini dilakukan pengambilan sampel tanah, tanah yang digunakan berasal dari salah satu wilayah di Kabupaten Malang. Lebih tepatnya pengambilan tanah untuk percobaan ini diambil di Desa Pandesari, Kecamatan Pujon, Kabupaten Malang.

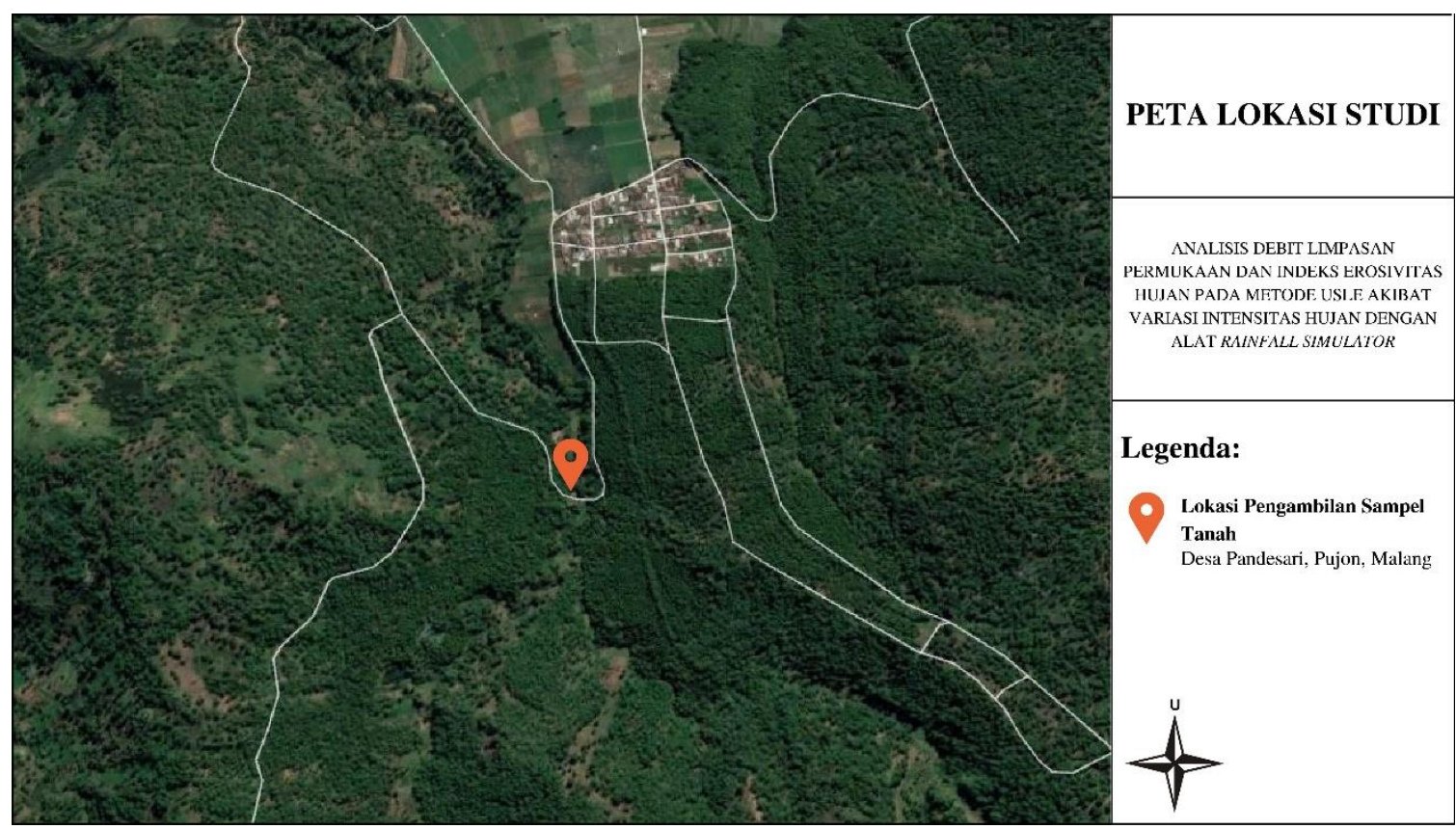




\section{Gambar 1: Titik lokasi pengambilan sampel tanah}

Studi ini dilakukan dengan cara simulasi pada alat rainfall simulator. Alat ini berada pada Laboratorium Hidrologi Jurusan Teknik Pengairan, Fakultas Teknik, Universitas Brawijaya. Data-data yang dibutuhkan adalah data hasil debit limpasan yang berasal dari alat rainfall simulator yang ada di Laboratorium Hidrologi Jurusan Teknik Pengairan. Alat rainfall simulator ini yaitu Armfield Hydraulics and Hydrology Software dengan S12-MKII-306 Hydrology. Untuk penelitian kali ini dilakukan dengan variasi intensitas hujan yang diatur pada alat tersebut, yaitu menggunakan intensitas hujan 0,5 liter/menit, 1,0 liter/menit, 1,5 liter/menit, dan 2 liter/menit.

Alat rainfall simulator tersebut juga memiliki kemampuan untuk merubah-ubah kemiringan alat, namun pada penelitian kali ini menggunakan kemiringan alat 5\% agar lebih sesuai pada lokasi pengambilan sampel yaitu Kecamatan Pujon. Sifat fisik tanah yaitu dengan mendapatkan presentase butiran dan permeabilitas tanah yang diuji pada Laboratorium Mekanika Tanah ITN Malang. Sedangkan untuk mengidentifikasi jenis tanah itu sendiri dengan menggunakan bantuan peta jenis tanah oleh Pemerintah Kabupaten Malang. Namun keadaan tanah untuk uji pada alat rainfall simulator di laboratorium tidak mengikuti pemadatan tanah seperti di lokasi studi.



Gambar 2: Peta jenis tanah di Kecamatan Pujon

\subsection{Metode}

Pada studi ini memiliki langkah-langkah untuk pengerjaan penelitian yaitu sebagai berikut:

1. Mendapatkan sampel tanah yaitu pada daerah di Desa Pandesari, Kecamatan Pujon, Kabupaten Malang. Menentukan kemiringan alat, yaitu dengan 5\%. Dan menentukan variasi intensitas hujan, penelitian ini menggunakan intensitas $0,5 \mathrm{liter} / \mathrm{menit}, 1,0 \mathrm{liter} / \mathrm{menit}, 1,5 \mathrm{liter} / \mathrm{menit}$, dan 2,0 liter/menit.

2. Melakukan pelaksanaan percobaan dengan menggunakan alat rainfall simulator.

3. Mendapatkan hasil dari alat rainfall simulator yaitu debit limpasan permukaan, dengan kemiringan alat $5 \%$ dari beberapa variasi intensitas hujan.

4. Melakukan perhitungan indeks erosivitas hujan dengan variasi intensitas hujan yang sudah ditentukan.

5. Melakukan analisis laju erosi dengan menggunakan metode USLE. 
6. Mendapatkan kesimpulan dari analisis pengaruh variasi intensitas hujan terhadap debit limpasan yang keluar, indeks erosivitas hujan dan laju erosi dengan menggunakan metode USLE.

Selain itu, adapun juga rancangan percobaan dengan menggunakan alat rainfall simulator, yaitu sebagai berikut:

1. Menyiapkan tanah sampel dari lokasi pengambilan sampel dan memastikan alat sudah siap dijalankan termasuk tandon sudah terisi cukup air.

2. Mengatur kemiringan alat dengan 5\% dan besar intensitas sesuai percobaan yang direncanakan.

3. Menyiapkan laptop yang sudah terpasang aplikasi Armfield Hydraulics and Hydrology Software dengan S12-MKII-306 Hydrology, dan memasangkan USB dari alat rainfall simulator ke laptop, ditunjukkan dengan lampu indikator pada alat yang menyala berarti alat tersambung dengan perangkat.

4. Membuka aplikasi dan mengaturnya dengan menu pilihan "Exercise B" dan mengatur besarnya Rainfall Flow Rate yang ada di sana sesuai dengan intensitas yang akan diamati.

5. Menekan tombol berwarna hujau untuk menyalakan hujan pada alat rainfall simulator.

6. Saat air sudah mulai melimpas melalui outlet pada alat rainfall simulator maka apilikasi Armfield Hydraulics and Hydrology Software dengan S12-MKII-306 Hydrology sudah bisa memulai untuk merekam.

7. Saat waktu melimpas sudah 60 menit, alat rainfall simulator bisa dimatikan dengan tombol merah.

8. Setelah limpasan sudah mencapai konstan nol, maka aplikasi Armfield S12-MKII-306 Hydrology sudah bisa dihentikan.

9. Hasil sebit limpasan yang sudah terekam di laptop berupa tabel dan grafik, kemudian hasil tersebut dapat disimpan pada folder yang diinginkan.

\section{Hasil dan Pembahasan}

\subsection{Jenis Tanah}

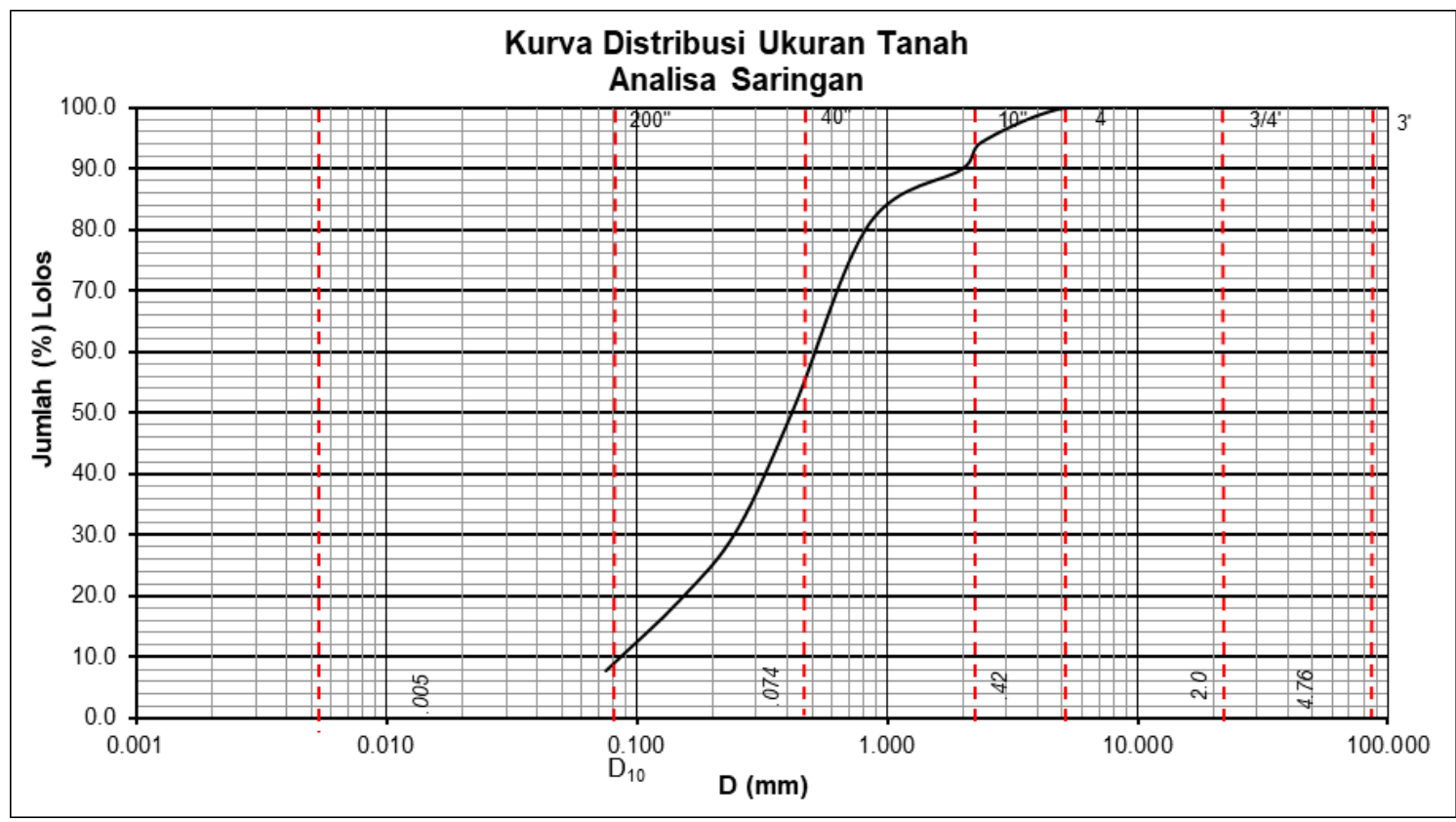

Gambar 3: Kurva distribusi butiran sampel tanah 
Dari hasil uji analisis butiran tanah pada lokasi studi, didapatkan klasifikasi tanah SP yaitu pasir gradasi buruk dan memiliki hasil nilai k permeabilitas sebesar $1,639 \times 10^{-5}$. Selain itu, pada peta jenis tanah di Gambar 2, sampel tanah termasuk ke dalam tanah andosol coklat kekuning-kuningan.

\subsection{Perhitungan Debit Limpasan}

Hasil dari debit limpasan dengan beberapa variasi intensitas hujan yaitu 0,5 liter/menit, 1,0 liter/menit, 1,5 liter/menit, dan 2,0 liter/menit, kemudian melakukan percobaan simulasi pada alat rainfall simulator. Setelah dilakukan tahapan-tahapan percobaan dengan alat rainfall simulator dan perangkat lunak bawaan alat tersebut yaitu Armfield Hydraulics and Hydrology Software seri S12MKII-206 Hydrology, setelah itu melakukan penyimpanan perekaman hasil debit limpasan dari alat tersebut.

\subsubsection{Rekapitulasi Hasil Debit Limpasan dengan Beberapa Intensitas Hujan}

Hasil debit limpasan dengan intensitas 0,5 liter/menit yaitu pada Gambar 4, kurva debit limpasan terjadi kenaikan limpasan terjadi antara menit ke 0:00 hingga menit ke 5:20. Kemudian limpasan tersebut menjadi relatif konstan hingga menit ke 51:20, dan kemudian grafik limpasan terjadi penurunan menuju ke debit 0,00 liter/menit.

Dengan intensitas hujan pada alat rainfall simulator sebesar 1,0 liter/menit, menghasilkan grafik yang ada pada Gambar 4. Grafik tersebut menunjukkan bahwa pada menit 0:00 hingga menit ke 7:20, terjadi limpasan permukaan yang semakin besar. Setelah itu debit limpasan menjadi relatif konstan hingga menit ke 49:00 dan kemudian kurva terjadi penurunan hingga debit menjadi 0,00 liter/menit.

Kemudian pada intensitas 1,5 liter/menit, limpasan permukaan pada alat rainfall simulator terjadi kenaikan pada menit 0:00 hingga menit 6:40 yang dapat dilihat pada Gambar 4. Menit selanjutnya hingga menit ke 50:40 debit limpasan menjadi relatif konstan, setelah itu grafik debit terjadi penurunan hingga menjadi 0,00 liter/menit.

Penelitian selanjutnya dengan intensitas 2,0 liter/menit, yang menghasilkan debit limpasan yaitu pada Gambar 4, dengan menit ke 0:00 hingga menit ke 8:20 hasil debit yang melimpas terjadi kenaikan. Selanjutnya hingga menit ke 52:00 debit limpasan sudah menjadi relatif konstan, dan kemudian terjadi penurunan kurva hingga debit yang melimpas menjadi 0,00 liter/menit.

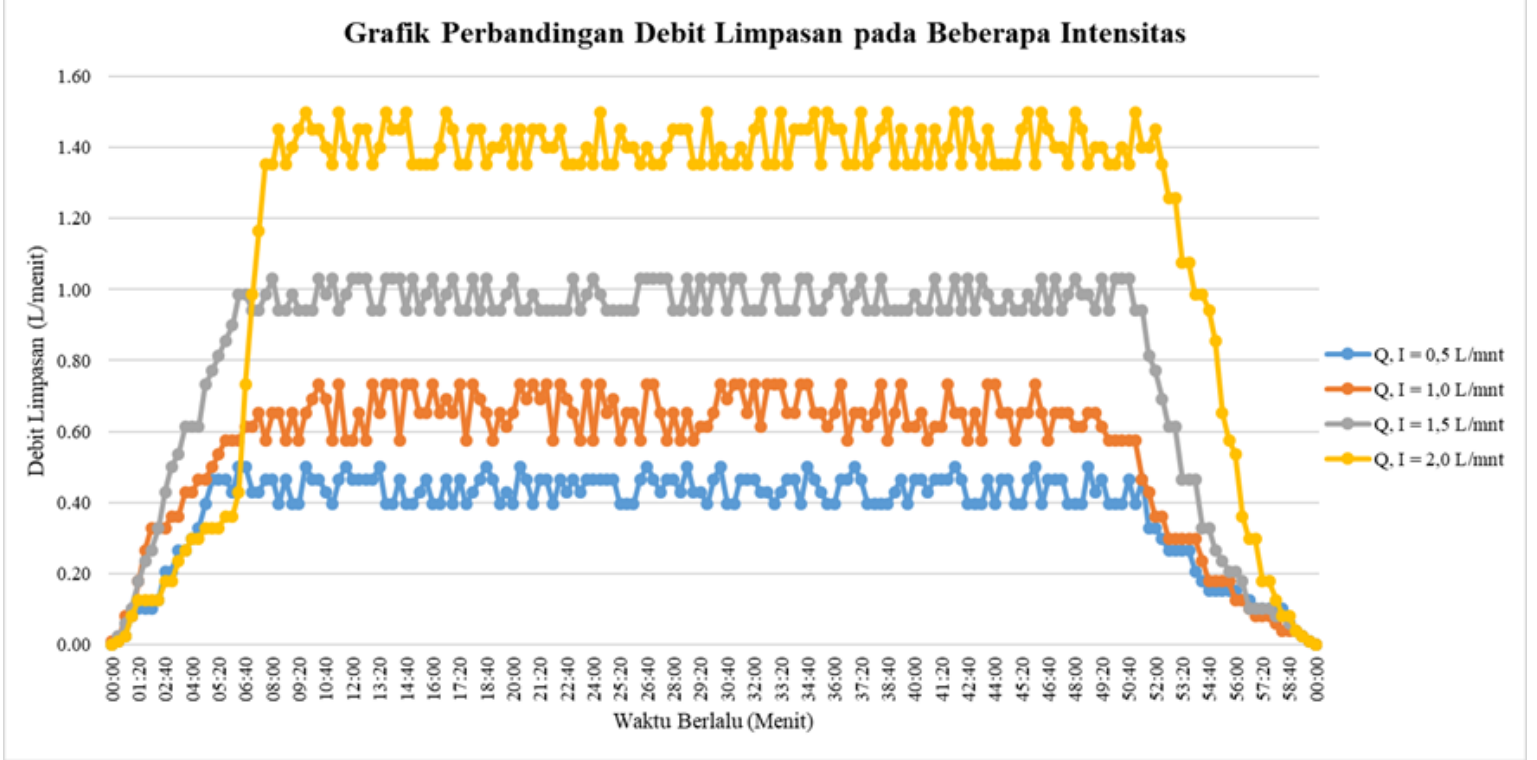

Gambar 4: Grafik perbandingan debit limpasan pada beberapa intensitas hujan 
Dari Gambar 4 tersebut, dapat terlihat perbandingan kurva dari hasil debit limpasan yang terjadi dengan beberapa variasi intensitas hujan. Intensitas yang ditunjukkan adalah 0,5 liter/menit, 1,0 liter/menit, 1,5 liter/menit, dan 2,0 liter/menit. Jika grafik hasil debit tersebut disatukan dan dibandingkan dengan satu sama lain, maka didapatkan hasil seperti Gambar 4. Keempat grafik tersebut, sama-sama memiliki kurva naik dan kurva turun yant tidak jauh berbeda, dan keempatnya memiliki bentuk puncak yang relatif merata. Puncak relatif merata ini terjadi karena pola distribusi intensitas hujannya merata [7].

Menurut hasil grafik perbandingan debit limpasan pada beberapa intensitas, dapat diketahui bahwa semakin kecil intensitas hujan yang terjadi, maka semakin kecil juga besar debit limpasan permukaan yang keluar. Sedangkan semakin besar intensitas hujan yang terjadi, maka semakin besar pula debit limpasan yang keluar.

\subsubsection{Hubungan Intensitas Hujan dan Debit Limpasan}

Setelah didapatkan hasil dari debit limpasan pada beberapa intensitas hujan, kemudian hasil debit limpasan tersebut dirata-rata dan dibuat hubungan intensitas hujan dengan debit limpasan.

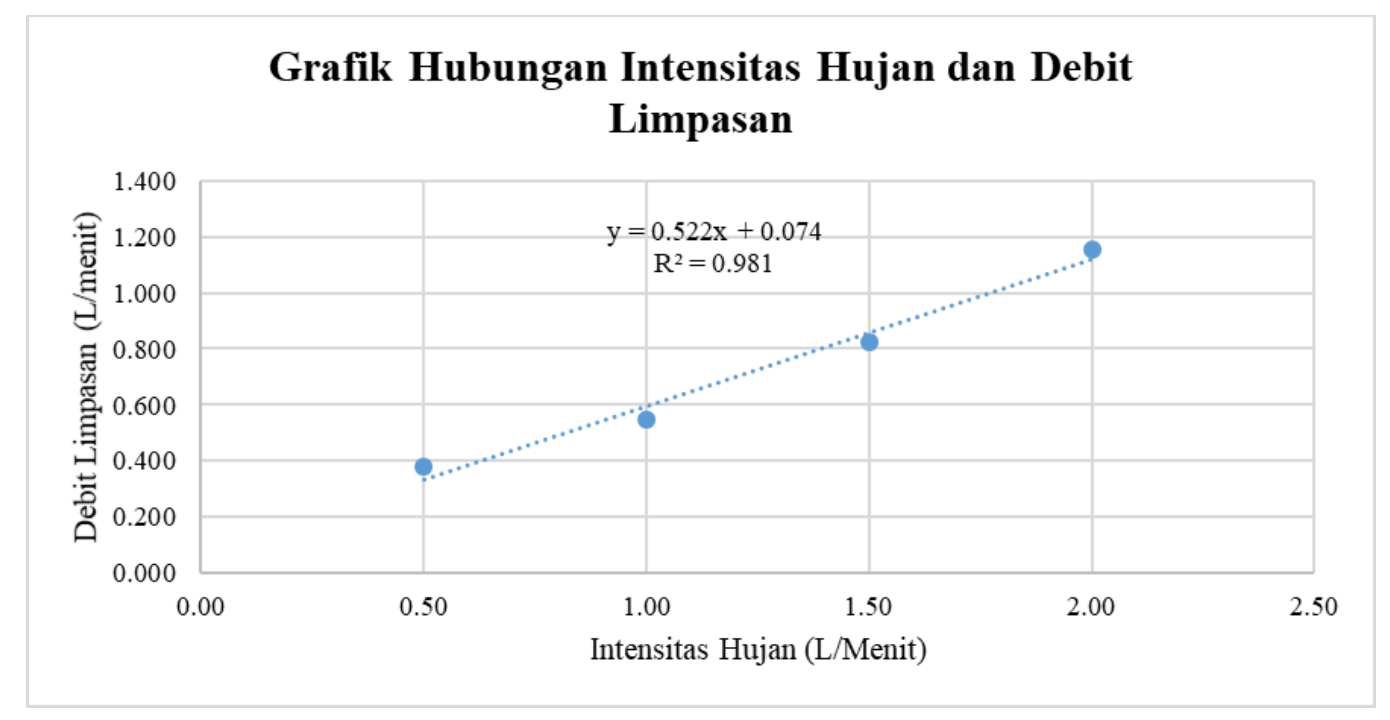

Gambar 5: Grafik hubungan intensitas hujan dan debit limpasan

Dari grafik pada Gambar 5, yang menunjukkan hubungan intensitas hujan dan debit limpasan, dapat diketahui bahwa semakin besar intensitas hujan yang terjadi maka semakin besar juga debit limpasan yang dihasilkan. Hubungan intensitas hujan dan debit limpasan ini juga menunjukkan koefisien determinasi $\mathrm{R}^{2}=0,981$. Hal tersebut berarti bahwa variabel bebas $(\mathrm{x})$ yaitu intensitas hujan memengaruhi variabel terikat (y) yaitu debit limpasan sebesar 98,1\%.

\subsection{Perhitungan Indeks Erosivitas Hujan}

a) Mengkonversi intensitas hujan pada alat rainfall simulator

Intensitas hujan adalah tinggi atau kedalaman air hujan per satuan waktu [8].

Data:

Intensitas hujan $\quad: 0,5$ liter/menit

Luasan lahan pemodelan : 2,0 $\mathrm{m}^{2}$

Perhitungan: 
Intensitas hujan

$$
\begin{aligned}
& =\frac{0,0005 \mathrm{~m}^{3}}{0,01667 \mathrm{jam}} \div \text { luas }\left(\mathrm{m}^{2}\right) \\
& =\frac{0,0005 \mathrm{~m}^{3}}{0,01667 \mathrm{jam}} \times \frac{1}{2 \mathrm{~m}^{2}} \\
& =\frac{0,5 \mathrm{~mm}}{0,03333 \mathrm{jam}} \\
& =15 \mathrm{~mm} / \mathrm{jam}=1,50 \mathrm{~cm} / \mathrm{jam}
\end{aligned}
$$

Pers. 1

b) Menghitung energi hujan

Menghitung energi hujan bisa dilakukan dengan persamaan sebagai berikut [1]:

$$
\begin{aligned}
E \quad & =210+89 \log I \\
& =210+89(0,179) \\
& =225,672 \text { ton.m ha- } \mathrm{cm}^{-1}
\end{aligned}
$$

Pers. 2

c) Menghitung indeks erosivitas hujan $(R)$ pada alat rainfall simulator

Data:

$$
\begin{array}{ll}
I_{30} & =1,5 \mathrm{~cm} / \mathrm{jam} \\
E & =225,672 \text { ton. } \mathrm{m} \mathrm{ha}^{-1} \mathrm{~cm}^{-1}
\end{array}
$$

Perhitungan:

$$
\begin{aligned}
E I_{30}=R & =E\left(I_{30} \times 10^{-2}\right) \\
& =225,672\left(1,5 \times 10^{-2}\right) \\
& =3,385 \text { ton.m.cm ha-1 }
\end{aligned}
$$

Pers. 3

\subsubsection{Rekapitulasi Hasil Perhitungan Indeks Erosivitas Hujan}

Dari Tabel 1, dapat dilihat bahwa dengan variasi intensitas hujan dalam penelitian, akan mendapatkan nilai energi hujan yang bervariasi pula. Sehingga menghasilkan indeks erosivitas hujan yang berbeda dari satu sama lain. Dengan intensitas yang lebih kecil akan menghasilkan indeks erosivitas hujan yang kecil pula, dan semakin tinggi intensitas hujan yang terjadi akan semakin besar indeks erosivitas hujan yang dihasilkan.

\section{Tabel 1: Rekapitulasi perhitungan indeks erosivitas hujan dengan beberapa intensitas hujan}

\begin{tabular}{ccccc}
\hline No & $\begin{array}{c}\text { Intensitas Hujan } \\
(\mathrm{L} / \mathrm{menit})\end{array}$ & $\begin{array}{c}\text { Intensitas Hujan } \\
(\mathrm{cm} / \mathrm{jam})\end{array}$ & $\begin{array}{c}E \text { (ton.m ha-1 } \mathrm{cm}^{-1} \\
\text { hujan })\end{array}$ & $E I_{30}$ (ton.m.cm ha $\left.{ }^{-1}\right)$ \\
\hline 1 & 0,5 & 1,50 & 225,672 & 3,385 \\
2 & 1,0 & 3,00 & 252,464 & 7,574 \\
3 & 1,5 & 4,50 & 268,136 & 12,066 \\
4 & 2,0 & 6,00 & 279,255 & 16,755 \\
\hline
\end{tabular}

\subsubsection{Hubungan Intensitas Hujan dan Indeks Erosivitas Hujan}

Untuk mendapatkan hubungan antara intensitas hujan dan indeks erosivitas hujan dibuatkan sebuah grafik, yaitu ditunjukkan pada Gambar 6. Dapat diketahui bahwa intensitas hujan dan erosivitas hujan memiliki hubungan keterkaitan dan saling berpengaruh, yaitu semakin besar intensitas hujan yang terjadi, maka semakin besar juga erosivits hujan tersebut. Dari Gambar 6 didapatkan pengaruh intensitas 
hujan dan erosivitas hujan ditunjukkan dengan koefisien determinasi $\mathrm{R}^{2}=0,999$ yang artinya variabel bebas (x) yaitu intensitas hujan memengaruhi variabel terikat (y) yaitu erosivitas hujan sebesar 99,9\%.

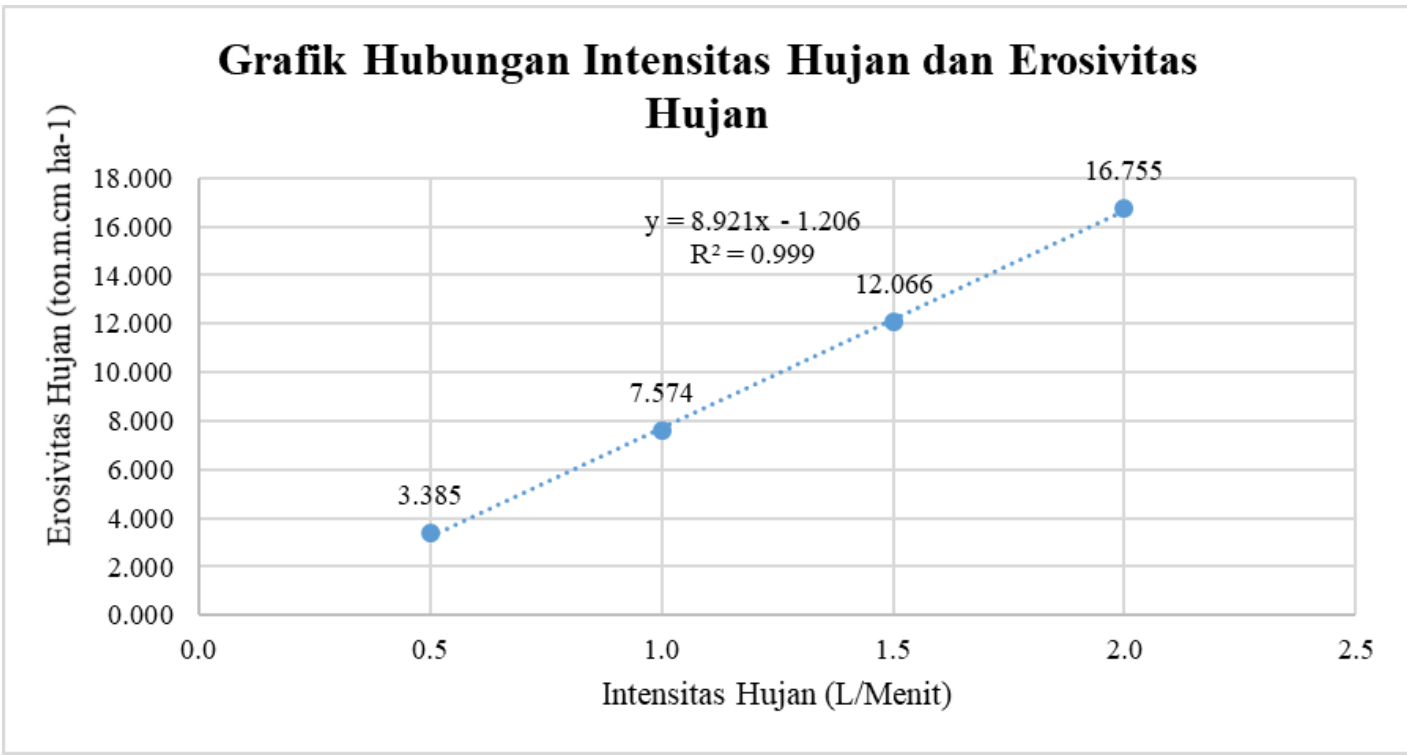

Gambar 6: Grafik hubungan intensitas hujan dan erosivitas hujan

\subsection{Perhitungan Laju Erosi dengan Metode USLE}

a) Faktor erosivitas hujan $(R)$

Indeks erosivitas hujan $(R)$ yaitu energi kinetik dan intensitas hujan maksimum selama 30 menit $\left(\mathrm{I}_{30}\right)$, sehingga dalam USLE nilai ini adalah $\mathrm{EI}_{30}$ [9]. Faktor erosivitas hujan dengan metode USLE pada penelitian ini menggunakan variasi intensitas hujan pada alat rainfall simulator. Besar faktor erosivitas hujan $(R)$ ini sudah dihitung sebelumnya dan menggunakan hasil pada Tabel 1 sesuai intensitas yang diteliti.

b) Faktor erodibilitas tanah $(K)$

Faktor ini menunjukkan resistensi partikel tanah terhadap pelepasan dan transportasi partikelpartikel tanah tersebut oleh adanya energi kinetik air hujan [2]. Faktor erodibilitas tanah $(K)$ ini merupakan seberapa ketahan suatu tanah untuk tererosi [10] Sampel tanah pada penelitian kali ini adalah berasal dari salah satu daerah di Kecamatan Pujon, Kabupaten Malang. Menggunakan peta jenis tanah pada Gambar 2, sehingga didapatkan di Desa Pandesari, Kecamatan Pujon memiliki jenis tanah andosol coklat kekuning-kuningan. Sehingga pada jenis tanah tersebut, nilai erodibilitas $\operatorname{tanah}(K)$ yaitu 0,223 .

c) Faktor gabungan panjang dan kemiringan tanah $(L S)$

Pada alat rainfall simulator yang dipakai untuk penelitian ini memiliki panjang 2 meter, sehingga panjang lahan pada faktor ini menggunakan panjang alat tersebut. Dan untuk penelitian ini sudah ditentukan yaitu menggunakan kemiringan alat 5\%, angka tersebut digunakan sebagai faktor kemiringan tanah. Perhitungan faktor $L$ dan $S$ ini dengan persamaan sebagai berikut [2]:

$$
\begin{aligned}
L S & =L^{1 / 2}\left(0,00138 S^{2}+0,00965 S+0,0138\right) \\
& =2^{1 / 2}\left(0,00138 \times 5^{2}+0,00965 \times 5+0,0138\right) \\
& =1,414(0,035+0,048+0,014) \\
& =0,137
\end{aligned}
$$


d) Faktor penutup vegetasi $(C)$

Untuk penelitian ini yang menggunakan alat rainfall simulator tidak menggunakan vegetasi sama sekali. Sehingga faktor penutup vegetasi $(C)$ yaitu tanah kosong tidak diolah memiliki nilai sebesar 0,950 .

e) Faktor pengelolaan dan konservasi tanah $(P)$

Tanah pada percobaan dengan alat rainfall simulator tidak dilakukan suatu tindakan konservasi lahan. Maka nilai faktor $P$ untuk tanpa tidakan konservasi sebesar 1,000.

3.4.1 Rekapitulasi Hasil Perhitungan Laju Erosi dengan Metode USLE

Data:

$$
\begin{array}{ll}
R & =3,385 \text { ton.m.cm ha-1 } \\
K & =0,223 \\
L S & =0,137 \\
C & =0,950 \\
P & =1,000
\end{array}
$$

Perhitungan:

$A \quad=R \times K \times L S \times C \times P$

$$
\begin{aligned}
& =3,385 \times 0,223 \times 0,137 \times 0,950 \times 1,000 \\
& =0,0979 \text { ton/ha/tahun }
\end{aligned}
$$

Tabel 2: Rekapitulasi hasil perhitungan laju erosi dengan beberapa intensitas hujan

\begin{tabular}{ccccccccc}
\hline No & $\begin{array}{c}\text { Intensitas } \\
\text { Hujan } \\
\text { (L/menit) }\end{array}$ & $\begin{array}{c}\text { Intensitas } \\
\text { Hujan } \\
(\mathrm{cm} / \mathrm{jam})\end{array}$ & $\begin{array}{c}R \\
\text { (ton.m.c } \\
\text { m ha-1) }\end{array}$ & $K$ & $L S$ & $C$ & $P$ & $\begin{array}{c}A \\
\text { (ton/ha/th) }\end{array}$ \\
\hline \hline 1 & 0,5 & 1,5 & 3,385 & 0,223 & 0,138 & 0,950 & 1,00 & 0,0979 \\
2 & 1,0 & 3,0 & 7,574 & 0,223 & 0,138 & 0,950 & 1,00 & 0,2191 \\
3 & 1,5 & 4,5 & 12,066 & 0,223 & 0,138 & 0,950 & 1,00 & 0,3490 \\
4 & 2,0 & 6,0 & 16,755 & 0,223 & 0,138 & 0,950 & 1,00 & 0,4847 \\
\hline
\end{tabular}

Dari Tabel 2 didapatkan nilai laju erosi dengan metode USLE dari beberapa variasi intensitas hujan. Dengan hasil tersebut, menunjukkan bahwa intensitas hujan yang berubah-ubah akan memengaruhi faktor erosivitas hujan dan membuat hasil laju erosi yang berbeda pula.

\subsubsection{Hubungan Intensitas Hujan dan Laju Erosi dengan Metode USLE}

Dengan hasil laju erosi pada Metode USLE dibuat grafik hubungan intensitas hujan dan laju erosi. Hal ini menunjukkan bahwa dengan variasi intensitas hujan berpengaruh pula pada besar laju erosinya, semakin besar intensitas hujan yang terjadi maka semakin besar laju erosi. Hubungan tersebut ditunjukkan pada Gambar 7 dengan ditunjukkan koefisien determinasi R2 $=0,999$, artinya variabel bebas (x) yaitu intensitas hujan memengaruhi variabel terikat (y) yaitu laju erosi sebesar 99,9\%. 


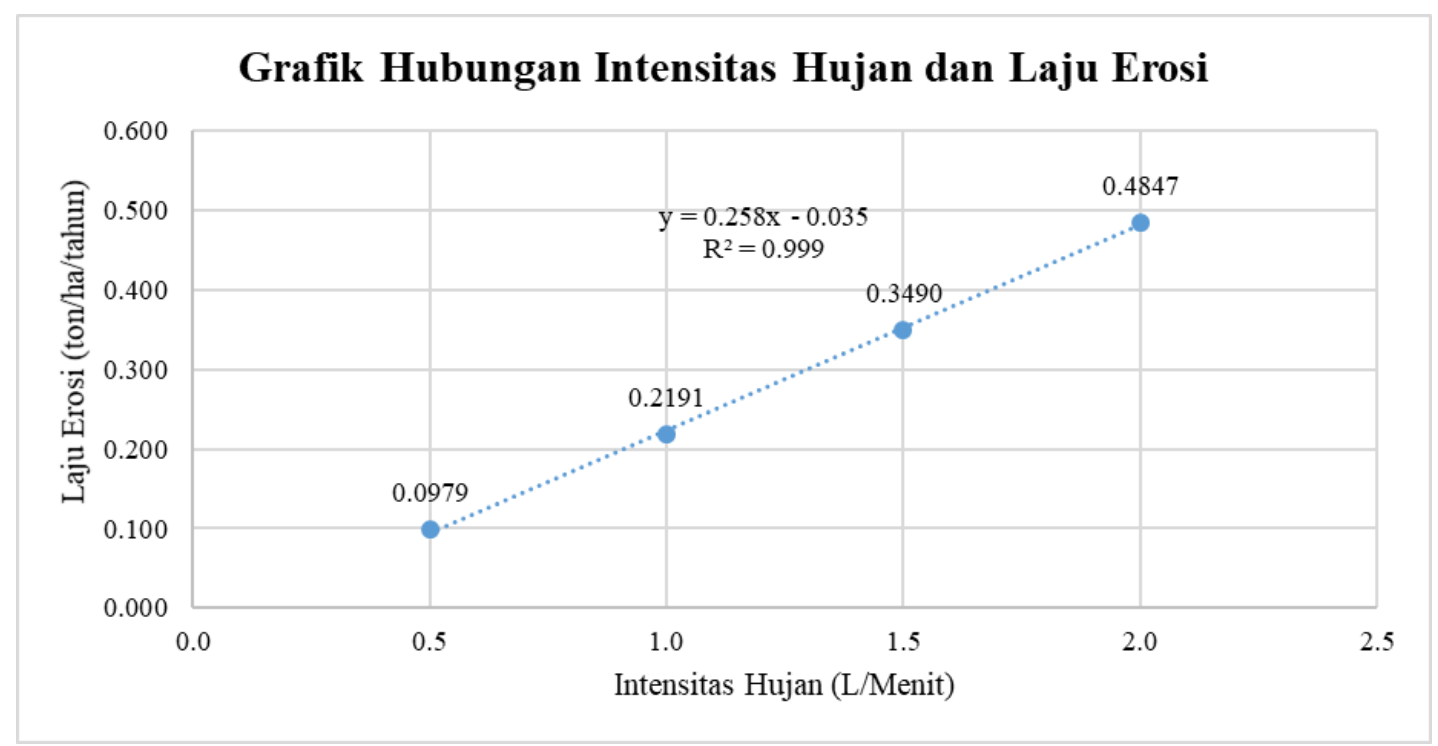

Gambar 7: Grafik hubungan intensitas hujan dan laju erosi

\section{Kesimpulan}

Besarnya pengaruh variasi intensitas hujan yang dilakukan pada alat rainfall simulator dengan kemiringan alat sebesar 5\%, didapatkan bahwa semakin besar intensitas hujan yag terjadi maka semakin besar debit limpasan yang keluar, begitupun sebaliknya. Hubungan intensitas hujan dan debit limpasan berbanding lurus dengan koefisien determinasi $\mathrm{R}^{2}=0,981$, yaitu intensitas hujan memengaruhi debit limpasan sebesar 98,1\%. Hasil indeks erosivitas hujan dengan variasi intensitas hujan pada alat rainfall simulator 0,5 liter/menit hingga 2,0 liter/menit memiliki hubungan berbanding lurus. Dengan koefisien determinasi $\mathrm{R}^{2}=0,999$, intensitas hujan memengaruhi besar nilai indeks erosivitas hujan sebesar 99,9\%. Dan sebesar 99,9\% intensitas hujan memengaruhi laju erosi pada metode USLE dengan ditunjukkan oleh koefisien determinasi $\mathrm{R}^{2}=0,999$. Untuk ke depannya, penelitian ini masih bisa untuk dikembangkan dengan cara memperbanyak variasi intensitas hujan agar hasil yang didapat lebih rinci dan akurat.

\section{Daftar Pustaka}

[1] Arsyad, S., Konservasi Tanah dan Air, Bogor: IPB Press, 2009.

[2] Asdak, C., Hidrologi dan Pengelolaan Daerah Aliran Sungai, Yogyakarta: Gadjah Mada University Press, 2010.

[3] Hardiyatmo, H. C., Tanah Longsor dan Erosi Kejadian dan Penanganan, Yogyakarta: Gadjah Mada University Press, 2012.

[4] Karyati, "Penaksiran Indeks Erosivitas Hujan di Kuching, Sarawak", Jurnal Gerbang Etam, vol. 10, no. 2, 2016.

[5] Puspaningrum, L., "Analisis Erosi Akibat Pengaruh Variasi Indeks Erosivitas Hujan dan Kemiringan Lereng dengan Menggunakan Alat Simulator Hujan”, skripsi, 2006.

[6] Andriyani, I., "Prediksi Laju Sedimentasi dan Erosi di Sub DAS Kemuning dengan Rainfall Simulator", Agritech, vol. 39, no. 3, pp. 179-187, 2019.

[7] Limantara, L. M., Hidrologi Praktis, Bandung: CV Lubuk Agung, 2010. 
[8] Suripin, Sistem Drainase yang Berkelanjutan, Yogyakarta: Andi, 2003.

[9] Wischmeier, W. H. and Smith, D. D., "Predicting Rainfall Erosion Losses: A Guide to Conservation Planing, USDA", Agriculture, handbook, no. 37, 1978.

[10] Utomo, W. H., Erosi dan Konservasi Tanah, Malang: Penerbit IKIP Malang, 1994. 